\section{WALKING WITH BLOOD FLOW RESTRICTION IMPROVES THE DYNAMIC STRENGTH OF WOMEN WITH OSTEOPOROSIS}

\author{
CAMINHADA COM RESTRIÇÃO DE FLUXO SANGUIINEO MELHORA AFORÇA DINÂMICA \\ DEMULHERES COM OSTEOPOROSE \\ CAMINATA CON RESTRICCIÓN DE FLUJO SANGUÍNEO MEJORA LA FUERZA DINÁMICA \\ DEMUJERES CON OSTEOPOROSIS
}

\begin{abstract}
Elísio Alves Pereira Neto 1,2
(Physiotherapist)

Simoni Teixeira Bittar ${ }^{1,2}$

(Physiotherapist)

Júlio César Gomes da Silva1,2

(Physical Education Professional)

Patrick Allan Souza Pfeiffer ${ }^{1,3}$

(Physical Education Professional)

Heleodório Honorato dos Santos ${ }^{1,3}$ (Physiotherapist and Physical

Education Professional)

Maria do Socorro Cirilo de Sousa ${ }^{1,2}$ (Physical Education Professional)

1. Universidade da Paraíba (UFPB), Programa de Pós-Graduação em Educação Física UPE/UFPB, PB, Brazil.

2. Universidade Federal de Paraíba (UFPB), Department of Physical Education, Laboratório de Cinantropometria e Desempenho Humano, João Pessoa, PB, Brazil. 3. Universidade Federal da Paraíba (UFPB), Department of Physical Therapist, Laboratório de Pesquisa de Equilíbrio, Dinamometria e Eletromiografia, João Pessoa, PB, Brazil.
\end{abstract}

\section{Correspondence:}

Elísio Alves Pereira Neto Rua Cardoso Vieira, 52, Centro, Santa Rita, Paraíba, PB, Brazil. 58300-070.

elisioapn@hotmail.com

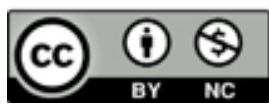

\begin{abstract}
Introduction: Improving strength levels is important to women with osteoporosis. Resistance and aerobic exercise are effective means of reaching this goal; however, the use of low-load exercises with blood flow restriction is an alternative to traditional methods of exercise to achieve the same strength gains in this population. Objective: To analyze the chronic effects of aerobic and resistance training combined with blood flow restriction on the maximal dynamic strength (MDS) of women with osteoporosis. Methods: Twenty women $\left(61.40 \pm 4.63\right.$ years of age, $\left.61.82 \pm 12.54 \mathrm{~kg}, 1.51 \pm 0.05 \mathrm{~m}, 27.16 \pm 5.55 \mathrm{~kg} / \mathrm{m}^{2}\right)$ were randomly assigned to four groups: 1 - high-intensity resistance training $(\mathrm{HI}) ; 2$ - low-intensity resistance training with blood flow restriction (LI-BFR); 3 - aerobic training with blood flow restriction (ABFR); and 4 - control group (CG). Unilateral knee extension MDS was assessed using the one-repetition maximum (1RM) strength test before and after the $6^{\text {th }}$ and $12^{\text {th }}$ weeks of intervention. The data were analyzed using repeated measures analysis of variance (ANOVA) with a Bonferroni post-hoc test performed using SPSS (version 21.0), considering a significance level of $\mathrm{P}<0.05$ for all tests. Results: Baseline comparisons showed that $\mathrm{HI}$ and $\mathrm{CG}$ had lower strength levels than $L I-B F R$ and ABFR groups $(P<0.05)$. The ABFR group exhibited a significant increase in MDS between the $1^{\text {st }}$ and the $6^{\text {th }}$ week $(9 \%, P=0.001)$ and between the $1^{\text {st }}$ and the $12^{\text {th }}$ week $(21.6 \%, P=0.008)$. The LI-BFR group exhibited increased MDS between the $1^{\text {st }}$ and the $6^{\text {th }}$ week $(10.1 \%, P=0.001)$, between the $1^{\text {st }}$ and the $12^{\text {th }}$ week $(24.2 \%, P=0.003)$ and between the $6^{\text {th }}$ and $12^{\text {th }}$ week $(12.8 \%, P=0.030)$. The HI group exhibited a significant difference between the $1^{\text {st }}$ and the $6^{\text {th }}$ week $(38.7 \%, P<0.001)$, between the $1^{\text {st }}$ and the $12^{\text {th }}$ week $(62 \%, P<0.001)$ and between the $6^{\text {th }}$ and $12^{\text {th }}$ weeks $(17.4 \%, P=0.020)$, whereas the $C G$ had no significant differences between the timepoints $(P>0.05)$. Conclusions: ABFR and LI-BFR effectively increased the MDS of women with osteoporosis.
\end{abstract}

Keywords: Aerobic exercise; Resistance training; Vascular closure devices.

\section{RESUMO}

Introdução: Melhorar os níveis de força éimportante para as mulheres com osteoporose. Os exercícios de força e aeróbicos são eficazes para atingir esse objetivo; no entanto, o uso de exercícios de baixa carga com restrição do fluxo sanguíneo é uma alternativa aos métodos tradicionais de exercício para atingir os mesmos ganhos de força nessa população. Objetivo: Analisar o efeito crônico do treinamento aeróbico e de força combinado com a restrição de fluxo sanguíneo sobre a força dinâmica máxima (FDM) de mulheres com osteoporose. Métodos: Vinte mulheres $\left(61,40 \pm 4,63\right.$ anos; $\left.61,82 \pm 12,54 \mathrm{~kg} ; 1,51 \pm 0,05 \mathrm{~m} ; 27,16 \pm 5,55 \mathrm{~kg} / \mathrm{m}^{2}\right)$ foram randomizadas em quatro grupos: 1 - treinamento de força de alta intensidade (Al); 2 - treinamento de força de baixa intensidade com restrição de fluxo sanguíneo (BIRFS); 3 - treinamento aeróbico com restrição de fluxo sanguíneo (ARFS) e 4 - controle (GC). A avaliação da força dinâmica máxima (FDM) da extensão unilateral do joelho foi realizada pelo teste de 1RM antes e depois da $6^{a}$ e $12^{a}$ semanas de intervenção. Para a análise dos dados realizou-se o teste ANOVA de medidas repetidas com teste de Bonferroni post-hoc no software SPSS (versão 21.0), considerando um nível de significância de $P<0,05$ em todas as análises. Resultados: As comparações antes da intervenção mostraram que os grupos Al e GC tinham menores níveis de força que os grupos ARFS e BIRFS $(P<0,05)$. O grupo ARFS apresentou aumento significativo na FDM entre a $1^{a}$ e a $6^{a}(9 \% ; P=0,001)$ e entre a $1^{a}$ e a $12^{a}$ semana $(21,6 \% ; P=0,008)$. O grupo BIRFS teve aumento da FDM entre a $1^{a}$ e a $6^{a}(10,1 \% ; P=0,001)$, entre a $1^{a}$ e a $12^{a}$ semana $(24,2 \% ; P=0,003)$ e entre a $6^{a}$ e 12a semana $(12,8 \% ; P=0,030)$. O grupo Al teve diferença significativa entre a 1a e a $6^{a}$ semana $(38,7 \% ; P<0,001)$, entre a 1a e a $12^{a}$ semana $(62 \% ; P<0,001)$ e entre a $6^{a}$ e a $12^{a}$ semana $(17,4 \% ; P=0,020)$, enquanto o $G C$ não apresentou diferença entre os pontos do tempo $(P>0,05)$. Conclusões: ARFS e BIRFS aumentaram efetivamente a FDM em mulheres com osteoporose.

Descritores: Exercício aeróbico; Treinamento de resistência; Dispositivos de oclusão vascular. 


\section{RESUMEN}

Introducción: Mejorar los niveles de fuerza es importante para las mujeres con osteoporosis. Los ejercicios de fuerza y aeróbicos son eficaces para alcanzar ese objetivo; sin embargo, el uso de ejercicios de baja carga con restricción del flujo sanguíneo es una alternativa a los métodos tradicionales de ejercicio para alcanzar los mismos aumentos de fuerza en esa población. Objetivo: Analizar el efecto crónico del entrenamiento aeróbico y de fuerza combinado con la restricción de flujo sanguíneo sobre la fuerza dinámica máxima (FDM) de mujeres con osteoporosis. Métodos: Veinte mujeres $\left(61,40 \pm 4,63\right.$ años; $\left.61,82 \pm 12,54 \mathrm{~kg}, 1,51 \pm 0,05 \mathrm{~m} ; 27,16 \pm 5,55 \mathrm{~kg} / \mathrm{m}^{2}\right)$ fueron aleatorizadas en cuatro grupos: 1 - entrenamiento de fuerza de alta intensidad (Al); 2 - entrenamiento de fuerza de baja intensidad con restricción del flujo sanguíneo (BIRFS); 3 - entrenamiento aeróbico con restricción del flujo sanguíneo (ARFS) y 4 - Control (GC). La evaluación de la fuerza dinámica máxima (FDM) de extensión unilateral de la rodilla se realizó mediante la prueba de 1RM antes y después de la $6^{a}$ y 12a semana de intervención. Para el análisis de los datos se realizó la prueba ANOVA de medidas repetidas con prueba de Bonferroni post hoc en el software SPSS (versión 21.0), considerando un nivel de significación de $P<0,05$ en todos los análisis. Resultados: Las comparaciones antes de la intervención mostraron que los grupos Aly GC tenían menores valores de fuerza que ARFS y BIRFS $(P<0,05)$. El grupo ARFS presentó un aumento significativo de la FDM entre las semanas 1 y $6(9 \% ; P=0,001)$ y entre las semanas 1 y $12(21,6 \% ; p=0,008)$. El BIRFS tuvo un aumento de la FDM entre las semanas 1 y $6(10,1 \% ; p=0,001)$, entre las semanas 1 y $12(24,2 \% ; p=0,003)$ y las semanas 6 y $12(12,8 \% ; P=0,030)$. El grupo Al tuvo una diferencia significativa entre las semanas 1 y $6(38,7 \% ; P<$ $0,001)$, entre las semanas 1 y $12(62 \%, P<0,001)$ y entre las semanas 6 y $12(17,4 \% ; p=0,020)$, mientras que el GC no presentó diferencia entre los puntos del tiempo ( $P>0,05)$. Conclusiones: ARFS y BIRFS aumentaron efectivamente la FDM en mujeres con osteoporosis.

Descriptores: Ejercicio aeróbico; Entrenamiento de resistencia; Dispositivos de cierre vascular.

\section{INTRODUCTION}

Osteoporosis is a chronic degenerative disease that usually results from physiological, biochemical and functional changes characteristic of the aging process. ${ }^{1}$ It is defined by decreased bone mineral density (BMD) with bone microarchitecture deterioration, leading to increased skeletal fragility and the risk of fractures. ${ }^{2}$

According to the World Health Organization (WHO), osteoporosis is the second greatest healthcare problem in the world after cardiovascular disease, and although it affects both sexes, the prevalence is higher in women than in men, with approximately 200 million people diagnosed with the disease worldwide. ${ }^{3}$ Decreased BMD combined with loss of strength leads to decreased functionality that promotes bone fragility and an increased risk of falls. ${ }^{4,5}$ Therefore, gaining or maintaining strength levels is important to prevent and treat the disease. Studies show that elderly people with better strength levels are less likely to develop osteoporosis and that performing aerobic and resistance training is a key tool to maintain BMD and functionality, prevent falls and gain strength.,6-10

Thus, high-intensity (>70\% one-repetition maximum (1RM)) resistance training $(\mathrm{HI})$ is effective among the elderly because it promotes stimuli and mechanisms that improve motor unit recruitment, tension of the muscle insertion into the bone, metabolite production and the appearance of microlesions that promote increased strength and BMD.4,6,10,11

Aerobic training (AT) is also an ideal tool to increase both BMD and strength. ${ }^{4,6,9}$ Conversely, studies show that performing low-intensity resistance training (LI) (20-40\% 1RM) combined with blood flow restriction (LIBFR) promotes the same strength gains as $\mathrm{HI}(\geq 70 \% 1 \mathrm{RM})^{11-14}$ and that AT performed with BFR also promotes significant strength gains, ${ }^{15}$ emerging as an alternative to optimize the rehabilitation of patients with osteoporosis.

This method consists of applying external pressure using a pressure cuff to cause BFR in working muscles, ${ }_{1}^{16}$ promoting a series of responses in the body, including increased recruitment of type II fibers, increased growth hormone $(\mathrm{GH})$ secretion, decreased myostatin levels and increased mechanistic target of rapamycin (mTOR) levels, increased nitric oxide synthesis and, especially, metabolite accumulation and stimulation of anaerobic growth factors. ${ }^{14,17,18}$ Few studies use training combined with BFR for rehabilitation, despite the evidence that it may be effective in the recovery of individuals with osteoporosis, ${ }^{14,19-22}$ and were not found any studies that investigated both types of training (aerobic and resistance) combined with BFR in individuals diagnosed with osteoporosis.

Thus, the aim of this study was to analyze the chronic effects of aerobic and resistance training combined with BFR on the maximal dynamic strength (MDS) of women with osteoporosis.

\section{MATERIALS AND METHODS}

\section{Sample}

Twenty women participated in the study and were randomly allocated into four groups: aerobic training with blood flow restriction (ABFR), low-intensity resistance training with blood flow restriction (LIBFR), high-intensity resistance training $(\mathrm{HI})$, and control group (CG). The sample size was calculated using $G^{*}$ Power $3.1^{\circledR}$ software (Ausseldorf, Bundesland - Germany) according to the procedures suggested by Beck.23 Based on a post-hoc analysis, according to the mean values and standard deviation (SD) of the data (pilot study), ${ }^{3}$ a number of 20 subjects was calculated using $a=0.05$, correction coefficient $=0.5$, and effect size $=0.8$, showing that the sample size sufficed to ensure an $89 \%$ statistical power.

The subjects met the following inclusion criteria to participate in the study: women; age $\geq 50$ years; diagnosed with osteoporosis in the femur area with a T score lower than -2.5 SD; and not performing lower limb resistance or aerobic training for at least 6 months. Women who missed more than $25 \%$ of the training sessions or missed 3 consecutive training sessions were excluded from the sample.

The study was approved by the Research Ethics Committee of the Lauro Wanderley University Hospital under protocol number 100/2013, and the subjects signed an informed consent form, prepared in accordance with the Declaration of Helsinki and Resolution 466/2012 of the National Health Council (Conselho Nacional de Saúde - CNS). 


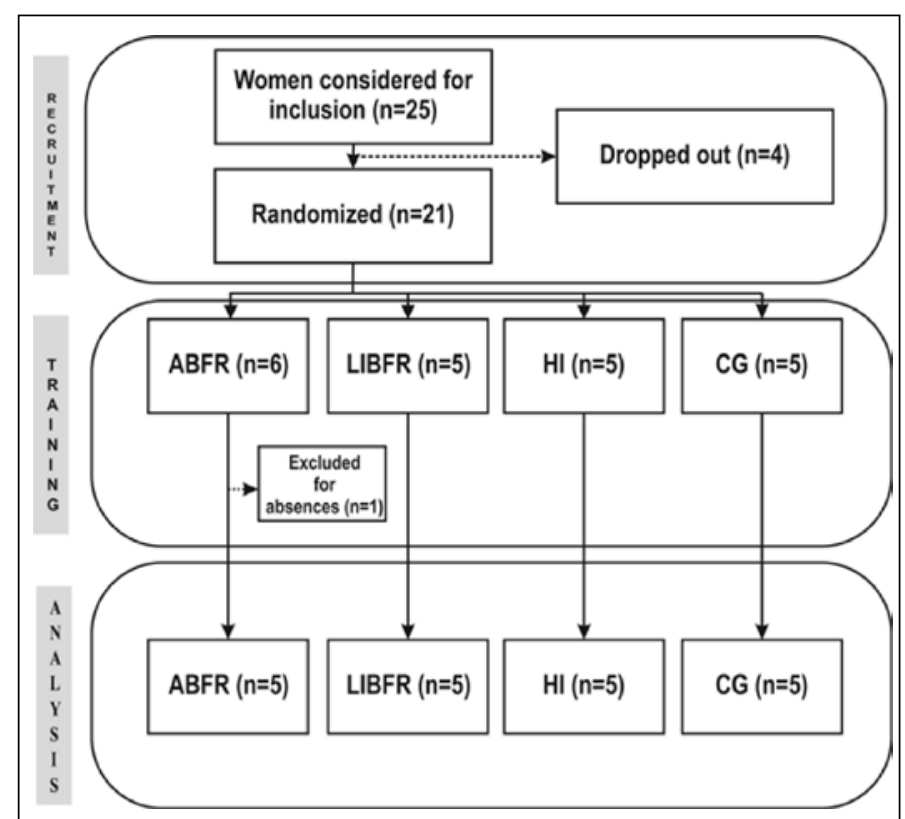

ABFR=aerobic training with blood flow restriction, LIBFR=low-intensity resistance training with blood flow restriction, $\mathrm{HI}=$ high-intensity resistance training, $\mathrm{CG}=$ control group.

Figura 1. Sampling flowchart.

\section{Blood flow restriction assessment}

The BFR point was assessed according to the protocol described by Laurentino et al., ${ }^{24}$ wherein the subject adopted the supine position, on the stretcher, while a blood pressure sphygmomanometer $(18 \mathrm{~cm}$ width $\times 80 \mathrm{~cm}$ length) was fixed on the proximal $1 / 3$ of the thigh and inflated until interrupting the auscultatory pulse of the posterior tibial artery detected by a vascular Doppler device (model DV2001 - Medpej ${ }^{\circledR}$, Ribeirão Preto/São Paulo), using $80 \%$ of the pressure value found for the LIBFR and ABFR groups, which used vascular restriction in their protocol.

\section{RM test}

The 1RM test performed in a leg extension machine, according to the guidelines of the American Society of Exercise Physiologists ${ }^{25}$ was used to assess the MDS in the unilateral knee extension movement. A set of 8 repetitions (50\% 1 RM), followed by a second set with 3 repetitions at 70\% 1RM with two-minute intervals between them, were performed for warm-up. After completing the warm-up, a three-minute interval was given before starting the test. The load was gradually increased until the subject was no longer able to perform the knee extension, and thus, the load reached in the attempt before the failure was considered the 1RM value. The maximal load had to be reached within 5 attempts, otherwise the test was discarded and performed again after at least 48 hours.

\section{Aerobic and resistance training protocol}

The training program lasted 12 weeks and was conducted with two weekly sessions separated by at least 48 hours, totaling 24 sessions. The aerobic exercise used was treadmill walking (65\% maximum heart rate (maxHR)), and the resistance exercise was unilateral knee extension. The experimental groups performed a light, three-minute warm-up on a stationary bicycle before performing the exercise. The $\mathrm{HI}$ group performed 4 sets of the exercise until concentric failure at 80\% 1RM (8.0 2.1 repetitions per set), with a two-minute interval and at a two-second speed of execution for the concentric phase and a two-second speed of execution for the eccentric phase controlled by a metronome (Winner, MT-30). The LIBFR group performed four sets of unilateral knee extension until failure at 30\% 1RM (7.0 \pm 3.3 repetitions per set, with no significant difference in the mean number of repetitions compared to that of the HI group) with a thirty-second interval and the same speed of execution as the $\mathrm{HI}$ group and with an inflated pressure cuff in the proximal area of the thigh at $80 \%$ BFR value, including during the intervals. The ABFR group performed treadmill walking for 15 minutes at $65 \%$ maxHR with an inflated pressure cuff, similarly to the LIBFR group, whereas the CG performed no exercise; all study volunteers were assessed at three time points (before intervention and at the 6th and 12th weeks).

\section{Statistical analysis}

The Statistical Package for the Social Science (SPSS - version 21.0) was used for data processing at a significance level of $P \leq 0.05$. After testing the normality of the data (Shapiro-Wilk's test) and homogeneity of variances (Levene's test), repeated measures ( $4 \times 3$ ) ANOVA was applied with the Bonferroni post-hoc test to analyze the training effect on the dependent variable: protocols $(\mathrm{HI} \times \mathrm{LIBFR} \times \mathrm{ABFR} \times \mathrm{CG}) \times$ assessments (before $\times 6^{\text {th }}$ $\times 12^{\text {th }}$ week). The effect size (ES) ${ }^{26}$ and percentage variation ( $\left.\triangle \%\right)$ were calculated to determine the magnitude of changes and variations in strength, respectively, between the first, second and third assessments.

\section{RESULTS}

Table 1 outlines the results of the pairwise analysis of groups using the intraclass correlation coefficient (ICC), showing that the sample was homogeneous in all anthropometric variables tested: very strong $(0.91$ to 0.99) for age, body mass and body mass index (BMI), and strong (0.61 to 0.90 ) for height, according to Araújo et al.. ${ }^{27}$

The intergroup comparison of MDS (Table 2) using repeated measures ANOVA showed a significant difference $(P<0.01)$ between groups, and the Bonferroni post hoc test showed significant differences between $\mathrm{HI}$

Table 1. Sample characterization with descriptive statistics (mean \pm standard deviation) of age, body mass, height and body mass index (BMI).

\begin{tabular}{c|c|c|c|c|c}
\hline Variables & HI & LIBFR & ABFR & CG & ICC \\
\hline Age (years) & $61.1 \pm 6.0$ & $62.6 \pm 4.3$ & $59.0 \pm 4.5$ & $62.2 \pm 4.0$ & $0.943^{* *}$ \\
\hline Body mass $(\mathrm{kg})$ & $57.3 \pm 8.5$ & $63.9 \pm 11.9$ & $67.4 \pm 16.8$ & $58.2 \pm 12.8$ & $0.963^{* *}$ \\
\hline Height $(\mathrm{m})$ & $1.50 \pm 0.05$ & $1.52 \pm 0.06$ & $1.49 \pm 0.06$ & $1.53 \pm 0.07$ & $0.899^{* *}$ \\
\hline BMI $\left(\mathrm{kg} / \mathrm{m}^{2}\right)$ & $25.4 \pm 4.5$ & $27.8 \pm 4.4$ & $30.2 \pm 7.6$ & $25.1 \pm 5.1$ & $0.964^{* *}$ \\
\hline
\end{tabular}

$\mathrm{HI}=$ high-intensity resistance training; $\mathrm{LBBR}=\mathrm{low}$-intensity resistance training with blood flow restriction; $\mathrm{ABFR}=$ aerobic training with blood flow restriction; $\mathrm{CG}=$ control group; $\mathrm{ICC}=$ intraclass correlation coefficient. Note: $\left.{ }^{* *}\right)=\mathrm{P}<0.01$.

Table 2. Intergroup comparative analysis of $1 \mathrm{RM}(\mathrm{kg})$ values using repeated measures ANOVA (Bonferroni post-hoc).

\begin{tabular}{c|c|c|c}
\hline Assessment & Group & Variation \% & P value \\
\hline \multirow{4}{*}{ Before } & HI $\times$ LIBFR & 59.7 & 0.032 \\
\cline { 2 - 4 } & HI $\times$ ABFR & 56.4 & $<0.001$ \\
\cline { 2 - 4 } & HI $\times$ CG & -8.0 & 0.794 \\
\cline { 2 - 4 } & LIBRF X ABFR & -2.0 & 0.911 \\
\cline { 2 - 4 } & LIBFR X CG & -42.0 & 0.019 \\
\cline { 2 - 4 } & ABFR X CG & -41.0 & 0.024 \\
\hline \multirow{5}{*}{ th week } & HI $\times$ LIBFR & 26.0 & 0.159 \\
\cline { 2 - 4 } & HI X ABFR & 23.2 & 0.159 \\
\cline { 2 - 4 } & HI X CG & -33.0 & 0.084 \\
\hline \multirow{5}{*}{$12^{\text {th }}$ week } & LIBRF X ABFR & -2.0 & 0.999 \\
\cline { 2 - 4 } & LIBFR X CG & -47.7 & 0.004 \\
\cline { 2 - 4 } & ABFR X CG & -46.2 & 0.004 \\
\hline & HI X LIBFR & 21.7 & 0.243 \\
\cline { 2 - 4 } & HI $\times$ ABFR & 16.8 & 0.359 \\
\cline { 2 - 4 } & HI X CG & -44.5 & 0.030 \\
\cline { 2 - 4 } & LIBRF X ABFR & -4.0 & 0.792 \\
\cline { 2 - 4 } & LIBFR X CG & -54.4 & 0.002 \\
\cline { 2 - 4 } & ABFR X CG & -52.5 & 0.004 \\
\hline
\end{tabular}

egend: $A B F R=$ aerobic training with blood flow restriction; $L I B F R=l o w$-intensity resistance training with blood flow restriction; $\mathrm{HI}=$ high-intensity resistance training; $\mathrm{CG}=$ control group. The variation $\%$ for all the moments (group $Y \times$ group Z) was calculated by the formula " $(Z$ group mean minus $Y$ group mean, divided by $Y$ group mean" and multiplied by 100 . 
$X$ LIBRR and ABFR ( $P=0.032, \triangle \%=59.7 ; P<0.001, \triangle \%=56.4$, respectively), and LIBFR and ABFR X CG (P=0.019, $\triangle \%=-42.0 ; P=0.024, \triangle \%=-41.0$, respectively) in the moment before; LIBFR and ABFR $\times$ CG (P=0.004, $\Delta \%=-47.7 ; P=0.004), \Delta \%=-46.2$, respectively) in the $6^{\text {th }}$ week; and $H$, LIBFR and ABFR $\times C G(P=0.030, \triangle \%=-44.5 ; P=0.002, \triangle \%=-54.4 ; P=0.004$, $\Delta \%=-52.5$, respectively) in the $12^{\text {th }}$ week.

The intragroup analysis (Table 3 ) using repeated measures ANOVA showed significant differences $(P<0.01)$ between the assessments, and the Bonferroni post-hoc test showed significant increases in MDS between Before $\times 6^{\text {th }}$ week $(P<0.001, \Delta \%=38.7, E S=1.3)$, Before $\times 12^{\text {th }}$ week $(P<0.001, \Delta \%=62, E S=2.1)$ and $6^{\text {th }} \times 12^{\text {th }}$ weeks $(P=0.02, \Delta \%=17.4 ; E S=0.88)$ in the $\mathrm{HI}$ group; Before $\times 6^{\text {th }}$ week ( $\left.P=0.001, \Delta \%=10.1, E S=0.28\right)$, Before $\times 12^{\text {th }}$ week $(P=0.003, \Delta \%=24.2, E S=0.68)$ and $6^{\text {th }} \times 12^{\text {th }}$ weeks $(P=0.03$, $\Delta \%=12.8, E S=0.45)$ in the LIBFR group; and Before $\times 6^{\text {th }}$ week $(P=0.001$, $\Delta \%=9, E S=0.4)$ and Before $\times 12^{\text {th }}$ week $(P=0.008, \Delta \%=21.6, E S=0.91)$ in the ABFR group. However, no significant increase was found in the CG at any of the three assessment time points.

\section{DISCUSSION}

The main finding of the present study was that ABFR, in the form of treadmill walking, promoted a significant increase in quadriceps MDS, with gains quite similar to those observed with LIBFR. Although no study has observed the chronic effects of AT and RT with BFR in individuals with osteoporosis, some groups ${ }^{9,15}$ have already observed strength gains when applying AT with BFR in adults, albeit without identifying significant changes with conventional AT.

A study ${ }^{28}$ with healthy young men who only performed ABFR on a treadmill, twice a day, for 36 sessions, showed a $7.4 \%$ increase in the MDS of knee extensor muscles. A much higher gain (21\%) in the quadriceps MDS of elderly women was obtained in the present study, with only 24 ABFR training sessions, than that obtained in the aforementioned study.

Abe et al. ${ }^{15}$ observed a significant increase (7.7\%) in the MDS of adults who performed ABFR training on a stationary bicycle for 15 minutes, 3 times a week, for 8 weeks, totaling 24 sessions, corroborating the results of the present study. However, the present study observed a higher (9\%) percentage variation in strength when comparing the Before and $6^{\text {th }}$ week time points, thus suggesting that walking combined with BFR is apparently more effective for strength gain than exercising on a stationary bicycle.

Another study ${ }^{29}$ using a treadmill walking protocol with sedentary elderly women, totaling 40 sessions, assessed $3.7 \%$ and $2.7 \%$ thigh and

Table 3. Intragroup comparative analysis of $1 \mathrm{RM}$ values using repeated measures ANOVA (Bonferroni post-hoc).

\begin{tabular}{c|c|c|c|c}
\hline Group & Assessment & Variation \% & ES & P value \\
\hline \multirow{4}{*}{$H$} & Before $\times 6^{\text {th }}$ week & 38.7 & 1.30 & $<0.001$ \\
\cline { 2 - 5 } & Before $\times 12^{\text {th }}$ week & 62.0 & 2.10 & $<0.001$ \\
\cline { 2 - 5 } & $6^{\text {th }} \times 12^{\text {th }}$ week & 17.4 & 0.88 & 0.020 \\
\hline \multirow{4}{*}{ LIBFR } & Before $\times 6^{\text {th }}$ week & 10.1 & 0.28 & 0.001 \\
\cline { 2 - 5 } & Before $\times 12^{\text {th }}$ week & 24.2 & 0.68 & 0.003 \\
\cline { 2 - 5 } & $6^{\text {th }} \times 12^{\text {th }}$ week & 12.8 & 0.45 & 0.030 \\
\hline \multirow{4}{*}{ ABFR } & Before $\times 6^{\text {th }}$ week & 9.0 & 0.40 & 0.001 \\
\cline { 2 - 5 } & Before $\times 12^{\text {th }}$ week & 21.0 & 0.90 & 0.008 \\
\cline { 2 - 5 } & $6^{\text {th }} \times 12^{\text {th }}$ week & 11.3 & 0.45 & 0.143 \\
\hline \multirow{4}{*}{ Control } & Before $\times 6^{\text {th }}$ week & 0.0 & 0.00 & 0.900 \\
\cline { 2 - 5 } & Before $\times 12^{\text {th }}$ week & -1.0 & 0.05 & 0.800 \\
\cline { 2 - 5 } & $6^{\text {th }} \times 12^{\text {th }}$ week & -1.0 & 0.05 & 0.920 \\
\hline
\end{tabular}

$\mathrm{HI}=$ high-intensity resistance training; $\mathrm{LBFR}=$ low-intensity resistance training with blood flow restriction; $\mathrm{ABFR}=\mathrm{ae}-$ robic training with blood flow restriction; $\mathrm{ES}=$ effect size. quadriceps volume increases, respectively $(P<0.05)$. Although that study did not assess MDS, the observed increase in the muscle cross-sectional area (CSA) consequently promotes an increase in MDS, thus corroborating the findings of the present study.

Several experimental studies and systematic reviews report that AT promotes positive changes in the bone quality of individuals with osteoporosis, ${ }^{4,10}$ but without obtaining the same gains in muscle strength $4,9,10$. However, the findings of the present study contradict those reports because ABFR training led to significant gains in MDS.

Some studies have already observed the positive effects of RT with BFR on strength in the elderly, ${ }_{1}^{20,21}$ although no published studies have observed these effects in subjects with osteoporosis. Accordingly, Yasuda et al. ${ }^{20}$ observed a significant increase of $26.1 \%$ in the quadriceps muscle strength in the elderly after 24 low-intensity resistance training sessions (20\% 1RM) combined with BFR.

Karabulut et al. ${ }^{21}$ compared the effects of LIBFR (20\% 1RM) with $\mathrm{HI}$ (80\% 1RM) among elderly people also with 24 training sessions and observed that both groups (LIBFR and HI) obtained strength gains (16\% and $23.5 \%$, respectively). Furthermore, Karabulut et al. ${ }^{22}$ also observed $31.2 \%$ and $19.1 \%$ gains in the knee extensor MDS of elderly people subjected to 18 training sessions in the $\mathrm{HI}$ and LIBFR groups, respectively, corroborating the results of the present study.

It is important to note that the LIBFR protocol used by Yasuda et al., ${ }^{20}$ for example, was very similar to that of the present study and that the strength gain obtained was also very similar (26.1\% in the aforementioned study and $24.2 \%$ in the present study). The available data are sufficient to state that both protocols ( $\mathrm{HI}$ and LIBFR) promote strength gain. However, BFR may be more advantageous and safer for training individuals with osteoporosis because this method uses a lower load to reach a similar strength gain.

Although strength gain is not the main objective of AT, the present study showed that the strength gains of the LIBFR group were very similar to those of the ABFR group. Increased GH release, recruitment of type II fibers, increased mTOR levels, high nitric oxide synthesis, increased stimulation of growth factors, reduced myostatin levels and metabolite accumulation and creation of a metabolic environment similar to that of RT may explain the significant changes in MDS promoted by AT with BFR. ${ }^{14,17,18}$

There is the need to highlight that, when comparing baseline measurements, the strength $\mathrm{HI}$ and CG groups showed significant smaller MDS levels than LIBFR and ABFR with elevated values of percentage variations (>40\%). Lower strength levels sometimes are related with worst functional capacity and may indicate that those subjects were less trained than the other or, at least, practice less physical activities on their daily life ${ }^{5,6}$. Because of that, following the theory that less trained individuals are easier to gain strength, specially due to neuronal adaptations, ${ }^{18}$ the greater MDS increase presented by the HI group was expected. This may limit some inferences because data showed that LIBFR and ABFR promote similar gains in strength, but smaller than the $\mathrm{HI}$ protocol, however this finding must be observed carefully since this may have happened due to the difference between MDS before intervention, being a limitation of the study.

Not monitoring the BMD or bone markers by bone densitometry or dual-energy x-ray absorptiometry (DXA) and blood tests, also could be considered as a limitation since it would allow us to observe changes in the BMD of the study subjects in addition to assessing the effects of different training protocols on strength, is a relevant limitation of this study. Other studies combining AT with BFR and RT with BFR should be performed, albeit assessing their effects at the bone level using bone markers or imaging tests. 


\section{CONCLUSIONS}

The results show that BFR combined with AT increases the MDS of women with osteoporosis. LIBFR and ATBFR promote similar strength gains, and both HIBFR and LIBFR effectively promote increases in MDS; LIBFR is more promising for individuals with osteoporosis. And even that HI protocol had promoted greater gains, this specific result should be carefully observed.
Including these exercises in a treatment protocol will most likely bring benefits not only to individuals with osteoporosis but also to those who may only tolerate low-intensity training (patients with multiple sclerosis and osteoarthritis, among others).

All authors declare no potential conflict of interest related to this article.

AUTHORS' CONTRIBUTIONS: Each author made significant individual contributions to this manuscript. EAPN (0000-0002-4943-418X)* and JCGS (0000-0002-3128-1883)*: were responsible for data collection, writing, data analysis and statistics and review; STB (0000-0003-3101-9217)* and PASP (0000-0001-7687-0692)*: article writing, statistical analysis and review; HHS (0000-0003-3951-8344)*: statistical analysis, writing and review; MSCS (0000-0001-5566-3248)*: article writing, data analysis and statistics, review and supervised writing of the manuscript. All authors read and approved the final manuscript. *ORCID (Open Researcher and Contributor ID).

\section{REFERENCES}

1. Camara FM, Gerez AG, Miranda MLJ, Velardi M. Capacidade funcional do idoso: formas de avaliação e tendências. Acta Fisitatr. 2008;15(4):249-56.

2. Pinto Neto AM, Soares A, Urbanetz AA, Souza ACA, Ferrari AEM, Amaral B, et al. Consenso brasileiro de osteoporose 2002. Rev Bras Reumatol. 2002;42:343-54.

3. Organización Mundial de La Salud. Informe preliminar y $3^{\circ}$ recomendaciones de una comisión de expertos de La Organización Mundial de La Salud sobre una estrategia global para La osteoporosis. Rev Esp Enfer Metab Oseas. 2000;9(2):78-83.

4. Barros HR, Ritti-Dias RM. Relação entre atividade física e densidade mineral óssea/osteoporose\&58: uma revisão da literatura nacional. Motriz. 2010;16(3):723-9.

5. Ribeiro RCL, Silva AIO, Modena CM, Fonseca MC. Capacidade funcional e qualidade de vida de idosos. Estud Interdiscip Envelhec. 2002;4:85-96

6. Aveiro MC, Navega MT, Granito RN, Rennó ACM, Oishi J. Efeitos de um programa de atividade física no equilíbrio e na força muscular do quadríceps em mulheres osteoporóticas visando uma melhoria na qualidade de vida. Rev Bras Ci e Mov. 2004;12(3):33-8

7. Dias R, Prestes J, Manzatto R, Ferreira CKO, Donatto FF, Foschini D, et al. Efeitos de diferentes programas de exercício nos quadros clínico e funcional de mulheres com excesso de peso. Rev. Bras. Cineantropom. Desempenho Hum. 2006;8(3):58-65.

8. Moreira LD, Oliveira ML, Lirani-Galvão AP, Marin-Mio RV, Santos RN, Lazaretti-Castro M. Physical exercise and osteoporosis: effects of different types of exercises on bone and physical function of postmenopausal women. Arq Bras Endocrinol Metab. 2014;58(5):514-22.

9. Raso V, Andrade EL, Matsudo SM, Matsudo VKR. Exercicio aeróbico ou de força muscular melhora as variáveis de aptidão física relacionadas a saúde em mulheres idosas? Rev Bras Ativ Fis e Saúde. 1997;2(3):36-49.

10. Silva KLGL. A influência da atividade física no aumento da densidade mineral óssea. Rev Digit Vida \& Saúde. 1999;1-19.

11. Yasuda T, Ogasawara R, Sakamaki M, Ozaki H, Sato Y, Abe T. Combined effects of low-intensity blood flow restriction training and high-intensity resistance training on muscle strength and size. Eur J Appl Physiol. 2011; 111(10):2525-33

12. Clark BC, Manini TM, Hoffman RL, Williams PS, Guiler MK, Knutson MJ, et al. Relative safety of 4 weeks of blood flow-restricted resistance exercise in young, healthy adults. Scand J Med Sci Sport. 2011;21 (5):653-62.

13. Takarada Y, Tsuruta T, Ishii N. Cooperative effects of exercise and occlusive stimuli on muscular function in low-intensity resistance exercise with moderate vascular occlusion. Jpn J Physiol. 2004; 54(6):585-92.

14. Grutter K, Bottino DA, Farinatti PTV, Oliveira RB. Aspectos metodológicos e aplicações clínicas dos exercícios com restrição do fluxo sanguíneo. Rev. HUPE. 2013;12(4):124-36.

15. Abe T, Fujita S, Nakajima T, Sakamaki M, Ozaki H, Ogasawara R, et al. Effects of low-intensity cycle training with restricted leg blood flow on thigh muscle volume and VO2max in young men. J Sport Sci Med. 2010; 9(3):452-8.

16. Kubota A, Sakuraba K, Koh S, Ogura Y, Tamura Y. Blood flow restriction by low compressive force prevents disuse muscular weakness. J Sci Med Sport. 2011;14(2):95-9.

17. Pearson SJ, Hussain SR. A review on the mechanisms of blood-flow restriction resistance training induced muscle hypertrophy. Sport Med. 2015;45(2):187-200.

18. Loenneke JP, Wilson GJ, Wilson JM. A mechanistic approach to blood flow occlusion. Int J Sports Med. 2010;31(1):1-4.

19. Loenneke JP, Young KC, Wilson JM, Anderson JC. Rehabilitation of an osteochondral fracture using blood flow restricted exercise: a case review. J Bodyw Mov Ther. 2013;17(1):42-5.

20. Yasuda T, Fukumura K, Fukuda $T$, Uchida $Y$, lida $H$, Meguro $M$, et al. Muscle size and arterial stiffness after blood flow-restricted low-intensity resistance training in older adults. Scand J Med Sci Sport. 2014;24(5):799-806.

21. Karabulut M, Abe T, Sato Y, Bemben MG. The effects of low-intensity resistance training with vascular restriction on leg muscle strength in older men. Eur J Appl Physiol. 2010;108(1):147-55.

22. Karabulut M, Bemben DA, SherkVD, Anderson MA, Abe T, Bemben MG. Effects of high-intensity resistance training and low-intensity resistance training with vascular restriction on bone markers in older men. Eur J Appl Physiol. 2011;111(8):1659-67.

23. Beck TW. The importance of a priori sample size estimation in strength and conditioning research J Strength Cond Res. 2013;27(8):2323-37.

24. Laurentino G, Ugrinowitsch C, Aihara AY, Fernandes AR, Parcell AC, Ricard M, et al. Effects of strength training and vascular occlusion. Int J Sports Med. 2008;29(8):664-7.

25. Brown LE, Weir JP. ASEP procedures recommendation I: accurate assessment of muscular strength and power. J Exerc Physiol. 2001;4(11):1-21

26. Rhea MR. Determining the magnitude of treatment effects in strength training research through the use of the effect size. J Strength Cond Res. 2004;18(4):918-20

27. Araújo AGF, Barbosa GM, Freire RA, Andrade PR, Ferreira JJA, Santos HH. Fidedignidade das medidas inter e intratestes com goniômetro universal e artrômetro podálico da amplitude ativa de eversão e inversão do tornozelo. Fisioter Pesq. 2014;21(4):339-45.

28. Abe T, Kearns CF, Sato Y. Muscle size and strength are increased following walk training with restricted venous blood flow from the leg muscle, Kaatsu-walk training. J Appl Physiol. 2006;100(5):1460-6.

29. Ozaki H, Sakamaki M, Yasuda T, Fujita S, Ogasawara R, Sugaya M, et al. Increases in thigh muscle volume and strength by walk training with leg blood flow reduction in older participants. J Gerontol A Biol Sci Med Sci. 2011;66(3):257-63. 